\title{
PILATES TRAINING INDUCES CHANGES IN THE TRUNK MUSCULATURE OF ADOLESCENTS
}

\author{
TREINAMENTO COM PILATES INDUZ ALTERAÇÕES NA MUSCULATURA DO TRONCO DE ADOLESCENTES \\ ENTRENAMIENTO DE PILATES INDUCE CAMBIOS EN LA MUSCULATURA DEL TRONCODEADOLESCENTES
}

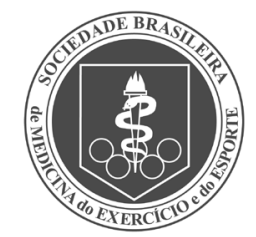

Original Article ARTIGO ORIGINAL Artículo Original
Noelia González-Gálvez (Physical Education Professional) María Carrasco Poyatos² (Physical Education Professional) Pablo Jorge Marcos-Pardo' (Physical Education Professional) Yuri Feito ${ }^{3}$

(Physical Education Professional) Rodrigo Gomes de Souza Vale ${ }^{4}$ (Physical Education Professional)

1. Sport Science Department, Universidad Católica de Murcia (UCAM). Murcia. Spain;

2. Education Science Faculty, Universidad de Almeria. Almeria. Spain;

3. Department of Exercise Science and Sport Management, Kennesaw State University. Georgia, United States

4. Laboratory of Exercise Physiology, Universidade Estácio de Sá, Cabo Frio, Rio de Janeiro, Brazil.

\section{Correspondence:}

Noelia González-Gálvez Sport Science Department. Universidad Católica de Murcia Av. de los Jerónimos, 135, 30107 Guadalupe, Murcia. Spain. ngonzalez@ucam.edu

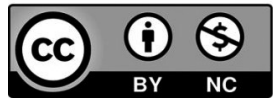

\section{ABSTRACT}

Introduction: The Pilates Method may be an appropriate form of exercise for improving trunk muscle strength, which can be a predictor of pain and musculoskeletal problems. Objective: The objective of this study was to assess the effects of the Pilates Method on muscle strength and endurance of the extensor and flexor muscles of the trunk in a group of adolescents. Methods: The sample consisted of 101 high-school students divided into two groups: an experimental group $(E G=81)$ and a control group ( $C G=20)$. The intervention was carried out twice a week for six weeks. Each session lasted 55 minutes, and was divided into three parts: warmup, main part, and cool down. Muscle strength was assessed by the Sörensen Test and the Bench Trunk-curl Test. The paired sample T-test, the T- test for independent samples, and Pearson's correlation coefficient were applied. The size of the effect (d) was determined. Results: The EG showed significant improvements in both tests (+34.77 points; +18.55 points, respectively). No changes were observed in the CG. The effect size was high $(d>1.15)$ for both tests, which means that the results were improved in a large proportion of the participants. The control group showed a decline in strength of the trunk musculature. In the experimental group, both boys and girls showed significant improvements in both tests. This strength increase was enhanced for a large proportion of boys and girls ( $d>1.15)$. The effect size was high ( $\mathrm{d}>1.15)$ for both tests and for both sexes. Conclusion: Six-weeks after implementing the Pilates Method in Physical Education lessons, the muscle strength of the flexor and extensor muscles of the trunk in adolescents was improved. Level of Evidence Il; Therapeutic studies-Investigation of treatment results.

Keywords: Isometric contraction; Muscle strength; Physical education and training; Health promotion; Exercise therapy.

\section{RESUMO}

Introdução: O método Pilates pode ser uma forma adequada de exercício para melhorar a força dos músculos do tronco, que podem ser um preditor de dor e problemas musculoesqueléticos. Objetivo: O objetivo deste estudo foi avaliar os efeitos do método Pilates sobre a força muscular e resistência dos músculos extensores eflexores do tronco em um grupo de adolescentes. Métodos: A amostra foi composta de 101 estudantes do ensino médio divididos em dois grupos: um grupo experimental ( $G E=81$ ) e um grupo controle $(G C=20)$. A intervenção foi realizada duas vezes por semana durante seis semanas. Cada sessão durou 55 minutos e foi dividida em três partes: aquecimento, parte principal e relaxamento. A força muscular foi avaliada com o teste de Sörensen e o teste de flexão abdominal com apoio de pernas. Para a análise de dados, foram empregados o teste t de amostras pareadas, o teste t para amostras independentes e o coeficiente de correlação de Pearson. O tamanho do efeito (d) foi determinado. Resultados: O GE apresentou melhoras significativas em ambos os testes ( $+34,77$ pontos; $+18,55$ pontos, respectivamente). Não foram observadas alterações no GC. O tamanho do efeito foi alto $(d>1,15)$ para ambos os testes, o que significa que os resultados foram melhores em uma grande proporção de participantes. O grupo controle apresentou declínio da força muscular do tronco. No grupo experimental, meninos e meninas apresentaram melhoras significativas em ambos os testes. Esse aumento de força foi atingido por uma alta proporção de meninos e meninas $(d>1,15)$. O tamanho do efeito foi alto $(d>1,15)$ nos dois testes e sexos. Conclusão: Seis semanas depois da implantação do método Pilates nas aulas de educação física, a força muscular dos flexores e extensores do tronco aumentou nos adolescentes.

\section{Nível de Evidência ll; Estudos Terapêuticos - Investigação dos resultados do tratamento.}

Descritores: Contração isométrica; Força muscular; Educação física e treinamento; Promoção da saúde; Terapia por exercício.

\section{RESUMEN}

Introducción: El método Pilates puede ser una forma apropiada de ejercicio para la mejora de la fuerza de la musculatura del tronco, la cual puede ser un predictor de dolory problemas musculoesquéticos. Objetivo: El objetivo de este estudio fue evaluar los efectos del método Pilates sobre la fuerza musculary la resistencia de los músculos extensores y flexores del tronco en un grupo de adolescentes. Métodos: La muestra consistió en 101 estudiantes de secundaria divididos en dos grupos: un grupo experimental ( $G E=81$ ) y un grupo control (GC=20). La intervención se realizó dos veces a la semana durante seis semanas. Cada sesión duró 55 minutos y se dividió en tres partes: calentamiento, parte principal y relajación. La fuerza muscular se evaluó mediante la prueba de Sörensen y la prueba de flexión abdominal con apoyo de piernas. Se aplicaron pruebas $t$ de muestras pareadas $t$ de muestras independientes y el coeficiente 
de correlación de Pearson. Se determinó el tamaño del efecto (d). Resultados: El GE mostró mejoras significativas en ambas pruebas ( $+34,77$ puntos; $+18,55$ puntos, respectivamente). No se observaron cambios en el GC. El tamaño del efecto fue alto $(d>1,15)$ para ambas pruebas, lo que significa que los resultados mejoraron en una gran proporción de participantes. El grupo control mostró una disminución en la fuerza de la musculatura del tronco. En el grupo experimental, tanto los niños como las niñas mostraron mejoras significativas en ambas pruebas. Este aumento de la fuerza fue mayor para una alta proporción de niños y niñas $(d>1,15)$. El tamaño del efecto fue alto $(d>1,15)$ para ambas pruebas y para ambos sexos. Conclusión: Después de seis semanas de implementar el método Pilates en las clases de educación física, se mejoró la fuerza muscular de los flexores y extensores del tronco en adolescentes.

\section{Nivel de evidencia Il; Tipo de estudio: Estudios terapéuticos - Investigación de resultados de tratamiento.}

Descriptores: Contracción isométrica; Fuerza muscular; Educación y entrenamiento físico; Promoción de la salud; Terapia por ejercicio.

\section{INTRODUCTION}

Maintaining optimal strength levels in the trunk musculature is important for functional stability ${ }^{1}$, preventing spine disorders ${ }^{2}$, and back pain ${ }^{2}$. In addition, it has been linked with the ability to correct posture and influence the improvement of athletic performance 1 .

In children and adolescents, trunk muscle strength has shown a predictive value of back pain and musculoskeletal problems ${ }^{3}$. Several studies have demonstrated that a greater trunk strength in children predicts a lower prevalence of cervical and back pain in adulthood ${ }^{3,4}$. Moreover, studies show a relationship between low trunk muscles strength and the prevalence of lower back pain in adolescents ${ }^{5}$. Therefore, strengthening programs that include both, deep and superficial trunk muscles are recommended ${ }^{6}$. Among these training programs, we find the Pilates Method (PM), which has been attributed shown to reduce back pain, improve posture, flexibility, strength, coordination and balance among several population ${ }^{7}$. However, there are only few studies that have actually implement the PM among adolescents ${ }^{8-10}$, and any of them assesses abdominal strength, as an important factor in back pain.

The purpose of this study was set to assess the effect an exercise routine, based on the Pilates Method, has on muscular strength of the trunk extensor and flexor muscles among a group of school aged children, in order to prevent back pain in adults.

\section{MATERIALS AND METHODS}

This research was developed through a quasi-experimental design with control group (CG) and experimental group (EG), with pre-test and post-test, with analysis of intragroup and intergroup measures.

After 6 weeks of exercise with the PM, GE teenagers will improve significantly in their muscular strenght of the trunk extensor and flexor muscles; there will be significant differences in the scores of these test between experimental and control group, and between boys and girls; and MP is more effective in improving muscular strenght of the trunk extensor and flexor muscles than other specific programs.

Participants were selected from an elementary education center of the Region of Murcia (Spain). Inclusion criteria for each student included parental consent; to be free of musculoskeletal, neurological, cardiac, metabolic or rheumatic conditions; to actively participating in physical education sessions and regular evaluations; and to not miss more than one session of the program (attendance of $91.66 \%$ ).

Students with prior history of spine pathologies/injuries or who had received previous treatment for back injuries were excluded from the study, although they were part of their regular class groups during training. All parents and/or guardians were informed and signed free a consent form approved by the "Scientific and Ethical Committee" of the San Antonio Catholic University of Murcia (number of the ethics protocol: E(101701).

The sample consisted of 101 students (59 boys and 42 girls) randomly distributed into two groups: experimental group ( $E G, n=81$ ) and control group (CG, $n=20)$. The basic characteristics of the samples are presented in Table 1

All tests were performed by the same investigator, whose test in reliability was tested prior to the study with a double-blind study of 30 participants, obtaining a correlation coefficient higher than 95\%. All tests were performed twice with an interval of two weeks. They were performed without a warm-up and with bare feet.

\section{Height and Weight}

Height $(\mathrm{cm})$ and weight $(\mathrm{kg})$ were measured without shoes using digital medical scale SECA220k (Barcelona, Spain). Body mass index was calculated as kg-m2.

\section{Sörensen Test}

The isometric strength of the trunk extensor muscles was assessed using the Sörensen Test. This is the most common test performed in studies evaluating strength of the trunk extensor muscles. Its validity and reliability has been tested in both adults and adolescents ${ }^{11-18}$. Participants laid prone on the examining table with the upper edge of the iliac crests aligned with the edge of the table. The lower body was secured to the table by an assistant. With the arms behind the back the subjects were asked to maintain the upper body in a horizontal position for as long as possible ${ }^{19}$. The measurement was recorded in seconds, and the maximum amount of time was set to 240 seconds (Figure 1 and 2).

\section{Bench Trunk-curl Test}

The strength of the trunk flexor muscles was estimated by the Bench Trunk-curl test. The Bench Trunk-curl test (BTC) provides a safe exercise to assess abdominal strength isolating the abdominal muscles and reducing the involvement of the hip flexors while protecting the back ${ }^{20}$ and has shown to be valid and reliable $20-22$. To perform the test, each subject laid

Table 1. Sample characteristics (Mean \pm SD).

\begin{tabular}{c|c|c|c}
\hline \multicolumn{2}{c|}{} & CG $(\mathbf{n = 2 0})$ & EG $(\mathbf{n = 8 1 )}$ \\
\hline \multirow{2}{*}{ Age } & $15.0 \pm 0.5$ & $14.4 \pm 0.6$ \\
\hline \multirow{2}{*}{ Gender } & Boys & 14 & 45 \\
\cline { 2 - 4 } & Girls & 6 & 36 \\
\hline \multicolumn{2}{c}{ Weight $(\mathrm{kg})$} & $60.8 \pm 14.6$ & $63.7 \pm 14.6$ \\
\hline \multicolumn{2}{c}{ Height $(\mathrm{cm})$} & $163.5 \pm 8.3$ & $167.9 \pm 8.4$ \\
\hline \multicolumn{2}{c}{ BMl* $\left(\mathrm{kg} / \mathrm{m}^{2}\right)$} & $22.5 \pm 3.8$ & $22.5 \pm 4.3$ \\
\hline BMD= Body Mass Index & &
\end{tabular}




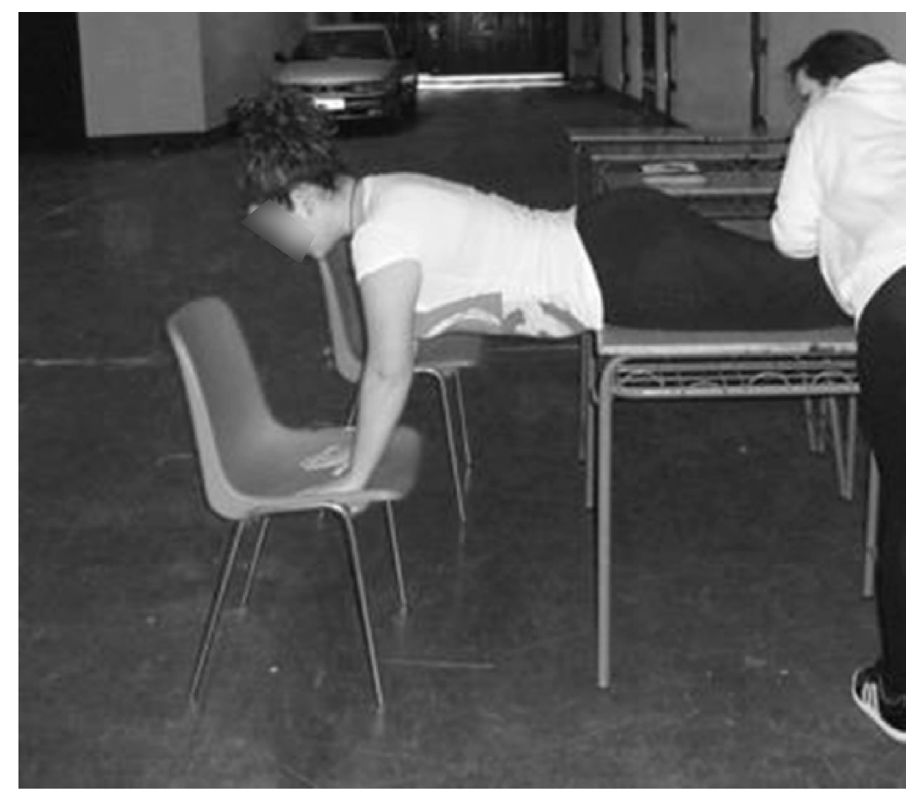

Figure 1. Sorensen test set position.

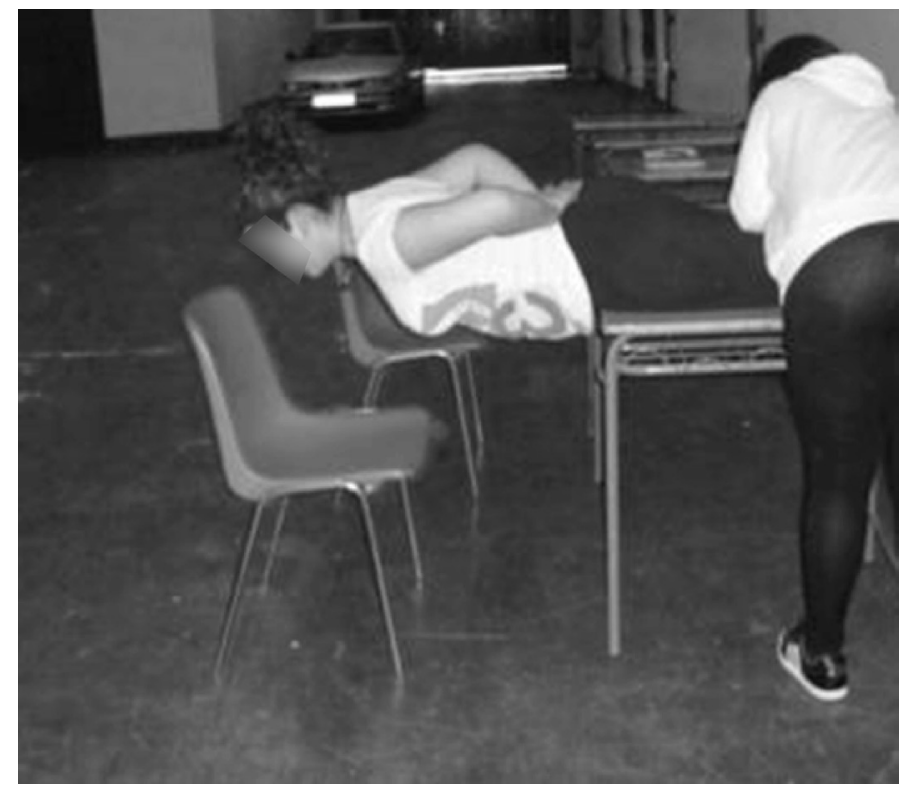

Figure 2. Sorensen test ejecution.

face up with both legs resting on a $46 \mathrm{~cm}$ high chair, with the hips and knees bent at a 90-degree angle. The arms were crossed over the chest holding the opposite arm's elbow (Figure 3). In this position, the subject performed a trunk curl so that the elbows touched the thigh (Figure 4) and returned the shoulders to the floor. Each participant performed as many repetitions as possible during 120 seconds $^{20}$.

\section{Exercise program}

This study was carried out throughout six-weeks, coinciding with the delivery of an instructional unit. Two 55 minutes sessions were performed each week. The experimental group participated in the PM instructional unit and the control group in their regular physical education classes. All students were asked to attend at least $92 \%$ of the lessons, so that no more than one day was missed by any of the students regardless of their group assignment.

The EG began the PM instructional unit at a basic level and gradually incorporated more complex exercises to each session. All sessions were divided into warm-up, main activity and cool down. The physical education teacher for each group conducted each instructional units. Prior to the

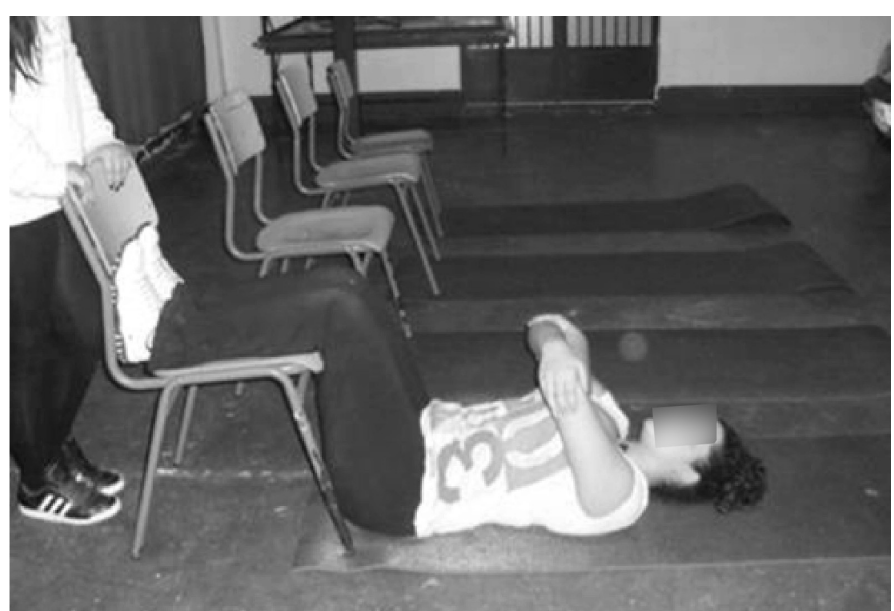

Figure 3. BTC test set position

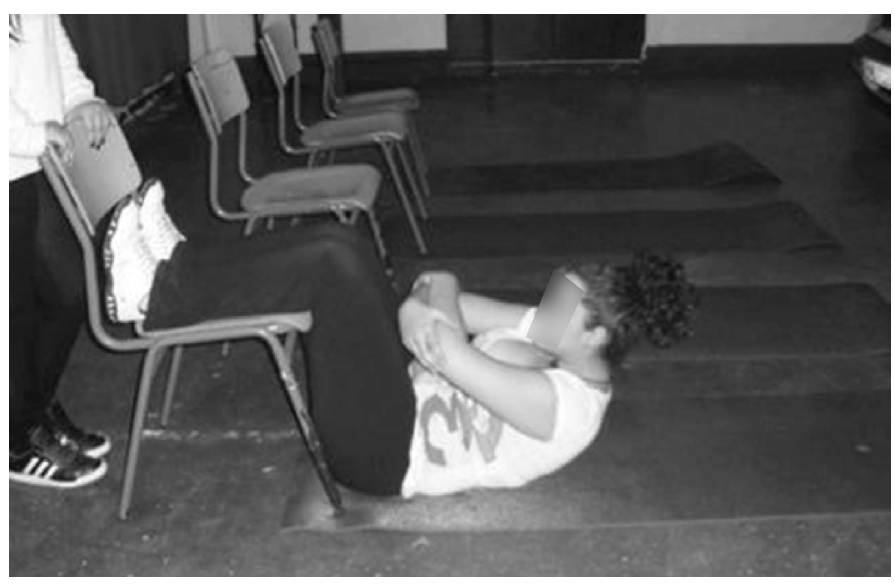

Figure 4. BTC test ejecution

beginning of this project, several meetings were conducted between the instruction and the research team to determine the exercises that would be performed during each session and to ensure correct implementation ${ }^{23}$.

\section{Teaching Development Unit}

The main activity section had a total duration of 41 minutes, accounting for $74.5 \%$ of the session. The first six-sessions were designed as an introduction to breathing techniques, integration of Pilates principles and a number of basic exercises (supine spine twist, abdominal preparation or half roll-up, one and double leg kick, swimming, shoulder bridge, half flexion back sitting, hip raise, hip raises, rolling like a ball, one leg stretch, double leg stretch, one leg circles and sidekick with extended arms). The following four sessions, included basic to intermediate exercises and the concept of a correct segmental placement was introduced. The last two sessions were used to consolidate the acquired knowledge and put all exercises learned into practice throughout the session. The cooling-down lasted seven-minutes and mainly focused on stretching and flexibility exercises.

\section{Statistical analysis}

After confirming all variables had a normal distribution, we carried out a descriptive analysis. A paired sample T-test was used to examine differences between pre- and post-testing of the Sörensen and Bench Trunk-curl test. The T- test for independent samples was employed to determine differences in the same variables between groups. The size of the effect (d) was determined either for the differences between groups or for the changes in each group. To establish correlations between the variables in each group, we used the Pearson's $r$ correlation coefficient. The statistical analysis was performed with SPSS 15.0 for Windows (SPSS Inc., Chicago, IL, USA). The significance level was set at $\mathrm{p}<0.05$. 


\section{RESULTS}

Table 2 shows the results of the pre-and post- BTC and Sörensen tests for both the experimental and control groups. Significant differences were observed for both the BTC and Sörensen test for the experimental group. The effect size was high ( $d>1.15$ ) for both test, which means that a large proportion of participants improved their results. The control group showed a decline in muscular strength of the trunk musculature. This decline however was not statistically significant but the effect size was high ( $d>1.15)$, consequently a large proportion of GC participants got worse their scores for both test. No significant correlations were found between variables.

Table 3 shows the test results according to gender. Significant improvements were found among GE boys and girls in the Sörensen and in the BTC test. This strength increase was enhanced for a high proportion of boys and girls ( $d>1.15)$. The effect size was high ( $d>1.15)$ for both test and for both gender, which means that a large proportion of participant improved their results. No significant changes were observed among CG participants, but the size effect was high ( $d>1.15)$, so most of them decreased their strength in both test. Which means large proportion of subjects to both boys and girls got worse their results for both test.

Table 2. Results of the trunk strength (Mean \pm SD).

\begin{tabular}{c|c|c}
\hline & EG & CG \\
\hline \multicolumn{3}{|c}{ Sörensen Test } \\
\hline Pre & $147.98 \pm 70.7$ & $139.40 \pm 50.4$ \\
\hline Post & $182.75 \pm 61.0^{*}$ & $114.50 \pm 44.8$ \\
\hline \multicolumn{3}{|c}{ BTC } \\
\hline Pre & $57.96 \pm 34.5$ & $57.15 \pm 35.1$ \\
\hline Post & $76.51 \pm 37.9^{*}$ & $50.05 \pm 26.3$ \\
\hline *Significant difference regarding pre-test $(\mathrm{p}<0.05)$
\end{tabular}

Table 3. Results of the trunk strength tests according to gender (Mean \pm SD).

\begin{tabular}{c|c|c|c|c}
\hline & \multicolumn{2}{|c}{ EG } & \multicolumn{2}{c}{ CG } \\
\hline & Boys $(\mathbf{n}=\mathbf{4 5})$ & Girls $(\mathbf{n}=\mathbf{3 6})$ & Boys $(\mathbf{n}=\mathbf{1 4})$ & Girls $(\mathbf{n}=\mathbf{6})$ \\
\hline \multicolumn{5}{c}{ Sörensen } \\
\hline Pre & $144.2 \pm 69.8$ & $152.7 \pm 72.5$ & $149.5 \pm 54.3$ & $115.8 \pm 32.3$ \\
\hline Post & $181.0 \pm 59.7^{*}$ & $184.9 \pm 63.4^{*}$ & $115.0 \pm 48.2$ & $113.3 \pm 39.8$ \\
\hline \multicolumn{5}{|c}{ BTC } \\
\hline Pre & $71.1 \pm 38.4$ & $41.6 \pm 19.1$ & $65.4 \pm 38.2$ & $38.0 \pm 16.3$ \\
\hline Post & $88.2 \pm 39.5^{*}$ & $61.9 \pm 30.6^{*}$ & $56.9 \pm 27.8$ & $34.0 \pm 12.9$ \\
\hline *Significant differences from the pre-test (p<0.01).
\end{tabular}

\section{DISCUSSION}

In the present study significant improvements were observed for both the flexor and extensor trunk muscles for the experimental group, compared to the control group.

These results support our hypothesis that we mentioned in the beginning of this article. Moreover, several authors have examined the benefits of the PM in the general population as well as in children and adolescents. However, to our knowledge, this is the first study that has assessed the influence of PM on the strength of the trunk muscles among adolescents during a physical education class.

There are a number of Pilates programs dedicated to adults, which show positive results in the strength of the trunk flexor muscles. Despite differences in the population, the two most similar studies, which use the PM with adults, are those of Kloubec ${ }^{24}$ and Sekendiz et al. ${ }^{25}$. Both of these research studies have the same duration as our intervention program, and applied similar measuring tools. Kloubec's $^{24}$ studied 50 participants between 25 and 65 years old, who were involved in a 12 sessions (2 sessions/week, 1h/session) Pilates intervention. The strength of the trunk flexor muscles was evaluated with the 'One minute sit-up test'. Significant improvements were observed in the experimental group with an improvement of 39\% (34.7 to 48.3 repetitions per minute).

Similarly, Sekendiz et al. ${ }^{25}$ recruited 38 women who took part in a five-week Pilates intervention, meeting three sessions per week. Significant improvement was observed in the one minute Curl-up test after the five-weeks, with participants in the experimental group improving by $107 \%$. Even though the percentage of improvement in the studies by Kloubec ${ }^{24}$ and Sekendiz et al. ${ }^{25}$ is larger than in this study, these differences may be due to the lower strength levels of their participants at baseline, or differences between the tests applied to measure abdominal strength. Additional investigators ${ }^{24-28}$ have demonstrated positive results in the muscular strength and strength of the trunk musculature of adults. However, these investigators applied different measuring protocols, including Isokinetic tests and pressure biofeedback units (PBU), which makes it impossible to compare to our findings.

Other training methods have been used to examine the trunk strength of school children. Mayorga et al. ${ }^{29}$ developed a specific program of abdominal strength (eight weeks, 14 sessions of 50 minutes), with a sample of 73 school age children. In this study, a significant improvement of $9 \%(P=0.01)$ was observed in the curl-up test among those in the experimental group (pre-test $=20.30 \pm 4.04$ repetitions, post-test $=$ $22.1 \pm 3.5$ repetitions; $p=0.01$ ) after the eight-weeks program. In comparison to our study, our program duration was lower, six versus eight weeks, but we employed the same frequency and duration of sessions. Thus, we can suggest that a shorter duration program, which is based on the Pilates method, could promote significant improvements in abdominal strength (23.5\% vs. 9\%) among school aged youth, compared to a program developed specifically for abdominal strength, such as that described by Mayorga et al. ${ }^{29}$

In addition, Moreira et al. ${ }^{30}$ analyzed the strength of the flexor (Webber Kraus Isometric Test) and extensor muscles of the trunk (Sörensen Test with $180^{\circ}$ shoulder flexion) in school-aged youth. The sample consisted of 58 students (control group $=30$, experimental group $=28$ ), with an average age of 12 years. They implemented an intervention program to improve the trunk strength, which was carried outside of school hours and lasted six-weeks (2 weekly sessions of 60 minutes). The results showed a great improvement in the trunk strength of the experimental group. The control group worsened the of the extensor musculature and did not present changes in the flexor one.

Although their sample is lower and its application is out of school hours, the characteristics, duration and frequency of the intervention program is similar to ours. However, the strength assessment of the trunk flexor muscles becomes difficult to compare with our study, considering they employed an isometric test. Furthermore, in relation to the trunk extensor muscles, it can be seen that the strength time is considerably higher in our study than in Moreira et al. ${ }^{30}$ This difference remains normal because of the different position of the arms during the test. Nonetheless, our findings are in agreement with those of Moreira et al. ${ }^{30}$ in relation to the improvements of the trunk extensor muscles; however, our protocol obtained an increase of $23.5 \%$ improvement compared to Moreira et al. ${ }^{30} 8.75 \%$.

Although our sample is larger than other similar studies, study's limitation could be this one. In further research it would be necessary an assessment the back pain in order to assessment the effect of the Pilates Method has on back pain in adolescents. 


\section{CONCLUSIONS}

After six-weeks of training within a school-based curriculum, the Pilates Method seems to provide significant improvements in strength of the flexor and extensor muscles of the trunk among school aged children. Based on these findings, and the work of others, we believe the Pilates Method could be utilized to improve functional stability and as a preventive tool for spine disorders and back pain among school-aged children.

All authors declare no potential conflict of interest related to this article

AUTHORS' CONTRIBUTIONS: Each author made significant individual contributions to this manuscript. This is a multi-institutional study with five authors. Each of the authors participated in the discussion of the results and the review and approval of the final version of the work for publication. NGG, MCP and PJMC developed the conception of the work design; NGG, YF and RGSV wrote the work and critical review of its content; MCP acquired the data for the work; MCP and PJMP analyzed the data for the work, and NGG, MCP, PJMP, YF and RGSV interpreted the data. NGG (0000-0002-7291-3306)*: conception of the work design, writing of the work and critical revision of its content, discussion of the results and final approval of the manuscript version to be published; MCP (0000-0001-5735-4908)*: conception of the work design, acquisition and analysis of the data for the work, discussion of the results, critical review of its content, discussion of the results and approval of the final version of the manuscript for publication; PJMP (0000-0003-1624-5013)*: conception of the work design, analysis and interpretation of the data for the work, discussion of the results, critical revision of its content and approval of the final version of the manuscript for publication; YF (0000-0001-6790-6294)*: interpretation of the data, writing of the work, discussion of the results and approval of the final version of the manuscript for publication; RGSV (0000-0002-3049-8773)*: interpretation of the data, writing of the work, discussion of the results, critical revision of its content, and approval of the final version of the manuscript for publication. *ORCID (Open Researcher and Contributor ID).

\section{REFERENCES}

1. Kovacs FM, Gestoso M, Vecchierini NM. Cómo cuidar su espalda. (2a. Ed.). Barcelona: Paidotribo; 2001.

2. Salminen JJ, Erkintalo M, Laine M, Pentti J. Low back pain in the young. A prospective 3-year follow-up study of subjects with and without low back pain. Spine. 1995; 20, 2101-8.

3. Calvo-Muñoz I, Gómez-Conesa A, Sánchez-Meca J. Prevalencia del dolor lumbar durante la infancia y la adolescencia. Una revisión sistemática. Rev Esp Salud Publica. 2012; 86: 331-56.

4. Mikkelsson LO, Nupponen H, Kaprio J, Kautiainen H, Mikkelsson M, Kujala UM. Adolescent flexibility endurance strength and physical activity as predictors of adult tension neck low back pain and knee injury: a 25 year follow up study. Br J Sports Med. 2006; 40: 107-13.

5. Lee JH, Hoshino Y, Nakamura K, Kariya Y, Saita K, Ito K. Trunk muscle weakness as a risk factor for low back pain. A 5-year prospective study. Spine. 1999; 24(1): 54-7.

6. Nicolaisen T, Jorgensen K. Trunk strength, back muscle endurance and low-back trouble. Scand J Rehabil Med. 1985; 17(3): 121-8.

7. González-Gálvez N, Sainz de Barand P, García-Paster T, Aznar S. Pilates method and research: literature review. Rev Int Med Cienc Act Fís Deporte. 2012; 12(48): 771-786.

8. Jago R, Jonker M, Missaghian M, Baranowski T. Effect of 4 weeks of Pilates on the body composition of young girls. Preventive Medicine. 2006; 42: 177-180

9. Kane K, Bell A. A Core Stability Group Program for Children with Developmental Coordination Disorder: 3 Clinical Case Reports. Pediatr Phys Ther. 2009; 21(4): 375-82.

10. Min-Kyoung J, So Yun S, Blair J, Se Jung H, Yun Mi K, Kyung-Jin B, Seong Kyeong K. Bone Density of Upper Arm, Spin and Femur after Pilates Training in Middle School Girls. Med Sci Sports Exerc. 2010; 42(5) S: 713.

11. Alaranta H, Hurri, H., Heliovaara, M., Soukka, A. and Harju, R. (1994). Nondynamometric trunk performance tests: reliability and normative data. Scand J Rehabil Med. 26: 211-5.

12. Champagne A, Descarreaux M. Back and hip extensor muscles fatigue in healthy subjects: task-dependency effect of two variants of the Sorensen test. Eur Spine J. 2008; 17: 1721-6.

13. Demoulin C, Vanderthommen M, Duysens C, Crielaard JM. Spinal muscle evaluation using the Sorensen test: a critical appraisal of the literature. Joint Bone Spine. 2006; 73: 43-50.

14. Geldhof E, Cardon G, De Bourdeaudhuij I, Danneels L, Coorevits P, Vanderstraeten G, De Clercq D. Effects of back posture education on elementary schoolchildren's back function. Spine. 2007; 16: 829-39.

15. Hyytiainen K, Salminen JJ, Suvitie T, Wickstrom G, Pentii J. Reproducibility of nine tests to measure spinal mobility and trunk muscle strength. Scand J Rehabil Med. 1991; 23: 3-10.
16. Moreau CE, Green BN, Johnson CD, Moreau SR. Isometric Back Extension Endurance Tests: A Review of the Literature. J Manipulative Physiol Ther. 20012; 4(2): 110-22.

17. Müller R, Strässle K, Wirth B. Isometric back muscle endurance: an EMG study on the criterion validity of the Ito test. J Electromyogr Kinesiol. 2010; 20(5): 845-50.

18. Norman S, Hannibal N S, Plowman SA, Looney MA, Brandenburg J. Reliability and Validity of Low Back Strength/Muscular Endurance Field Tests in Adolescents. J Phys Act Health. 2006; 3(Suppl. 2): 78-89.

19. Biering-Sorensen F. Physical measurements as risk indicators for low-back trouble over a one-year period. Spine. 1984; 9: 106-119.

20. Knudson D, Johnston D. Validity and Reliability of a bench trunk-curl test of abdominal endurance. J Strength Cond Res. 1995; 9(3): 165-9.

21. Knudson D. The validity of recent curl-up test in Young adults. J Strength Cond Res. 2001; 15(1): 81-5.

22. Knudson D, Johnston, D. Analysis of three test durations of the bench trunk curl. J Strength Cond Res. 1998; 12(3): 150-1.

23. González N, Carrasco M, Marcos PJ. El Método Pilates: Una propuesta didáctica para 30 de Educación Secundaria Obligatoria. Emás. 2013; 4(24): 8-20.

24. Kloubec J. Pilates for improvement of muscle endurance, flexibility, balance and posture. J Strength Cond Res. 2010; 24(3): 661-667.

25. Sekendiz B, Altun O, Korkusuz F, Akın S. Effects of Pilates exercise on trunk strength, endurance and flexibility in sedentary adult females. Exercise Physiology. J Bodyw Mov Ther. 2007; 11: 318-26.

26. García IE, De Barros SM, Saldanha M. Avaliação isocinética da musculatura envolvida na flexão e extensão do tronco: efeito do MP. Rev Bras Med Esporte 2004; 10(6): 487-90

27. Herrington L, Davies R. The influence of Pilates training on the ability to contract the transversus abdominis muscle in asymptomatic individuals. J Bodyw Mov Ther. 2005; 9: 52-7.

28. Emery K, De Serres S, McMillan A, Côté J. The effects of a Pilates training program on arm-trunk posture and movement. Clin Biomech. 2010; 25(2): 124-7.

29. Mayorga D, Viciana J, Cocca A, Miranda MT. Efecto del entrenamiento de la fuerza sobre la resistencia muscular abdominal en escolares pre-púberes. EFDeportes [Internet] 2010, 148. [Cited May 1, 2012]. Available in: http://www.efdeportes.com/efd148/resistencia-muscular-abdominal-en-pre-puberes.htm

30. Moreira RFC, Akagi FH, Wun PYL, Moriguchi CS, Sato TO. Effects of a school based exercise program on children's resistance and flexibility. Work. 2012; 41: 922-8. 